\title{
ANALISIS BEBAN KERJA PADA DEPARTEMEN QUALITY CONTROL
}

\author{
Aldi Irawan*, Eko Budi Leksono \\ Program Studi Teknik Industri, Fakultas Teknik, Universitas Muhammadiyah Gresik \\ Email: aldiirawan8585@gmail.com; eko_budileksono@umg.ac.id
}

Artikel masuk : 02-09-2020

\author{
Artikel direvisi : 16-11-2020 \\ *Penulis Korespondensi
}

Artikel diterima : 04-01-2021

\begin{abstract}
Abstrak -- PT XYZ ialah perusahaan yang bergerak di bidang industri pangan dengan menciptakan produk utama yaitu tepung terigu. Berdasarkan hasil analisis bisa diketahui bila pekerjaan yang dilaksanakan oleh tenaga kerja job desk analisa wajib tergolong tinggi. Masing-masing shift hanya terdapat 1 operator yang mengakibatkan operator tersebut tidak bisa menuntaskan pekerjaan tepat waktu serta akan menimbulkan dampak kelelahan akibat beban kerja yang melampaui batas. Penelitian ini bertujuan untuk menentukan jumlah kerja yang optimal berdasarkan beban kerja yang ada. Perhitungan beban kerja dilakukan dengan metode workload analysis selama 10 hari dengan jumlah pengamatan sebanyak 200 sampling. Hasil dari penelitian menunjukkan ratio delay pekerja sebesar 12.36\%, waktu siklus 2.45 menit, waktu normal 3.06 menit. waktu baku yang dibutuhkan untuk menyelesaikan tiap output analisa adalah 3.71 menit. Beban kerja pekerja berdasarkan volume pekerjaan, jumlah hari kerja, waktu baku, dan jam kerja untuk menyelesaikan pekerjaannya tiap shift memerlukan 2.75 orang. Hal tersebut menunjukkan beban kerja yang diterima pekerja tergolong tinggi atau melebihi kapasitas 1 orang pekerja. Usulan perbaikan yang diberikan untuk menangani beban kerja tersebut adalah dengan memperbanyak jumlah pekerja menjadi 3 orang.
\end{abstract}

Kata kunci: Tenaga Kerja; Waktu Baku; Workload Analysis

\begin{abstract}
PT XYZ is a company engaged in the food industry by creating a main product, namely wheat flour. Based on the results of observations, it can be seen if the work carried out by a mandatory job desk analysis worker is classified as high. Each shift has only 1 operator which results in the operator being unable to complete the work on time and will cause fatigue due to workload that exceeds the limit. This study aims to determine the optimal amount of work based on the existing workload. The workload calculation was carried out using the workload analysis method for 10 days with a total of 200 sampling observations. The result of this research shows that the worker delay ratio is $12.36 \%$, the cycle time is 2.45 minutes, the normal time is 3.06 minutes. The standard time required to complete each analysis output is 3.71 minutes. Workload of workers based on work volume, number of working days, standard time, and working hours to complete each shift requires 2.75 people. This shows that the workload received by workers is high or exceeds the capacity of 1 worker. The suggested improvement to handle the workload is to increase the number of workers to 3 people.
\end{abstract}

Keywords: Workforce; Standard Time; Workload Analysis

\section{PENDAHULUAN}

Beban kerja ialah perbedaan kemampuan pekerja dengan tuntutan kerja yang mesti dihadapi (Hariyati, 2011). Perbedaan yang begitu jauh menimbulkan pekerjaan tidak bisa dituntaskan sesuai dengan target yang telah ditetapkan. Workload Analysis (WLA) adalah strategi yang dapat digunakan untuk menghitung besarnya beban kerja yang ditimbulkan oleh kegiatan yang dilakukan (Budaya \& Ahmad, 2018).

Pengukuran beban kerja bertujuan untuk mendapatkan data mengenai tingkat efektivitas serta efisiensi suatu pekerjaan berlandaskan pada banyaknya pekerjaan yang mesti dituntaskan (Anisa \& Prastawa, 2019). Selain untuk men- 
dapatkan data mengenai tingkat efektivitas dan efisiensi suatu pekerjaan, Pengukuran jumlah jam kerja serta jumlah orang yang dibutuhkan untuk menuntaskan suatu pekerjaan merupakan fungsi dari pengukuran beban kerja (Ahmad, 2004). Pengukuran beban kerja juga dipengaruhi Rating Factor dan Allowance pekerja.

Dalam pengukuran beban kerja, ada dua cara untuk menentukannya, yaitu dengan Time Study (Stopwatch, Micromotion, Predetermined Time System), dan Work Sampling. Work sampling digunakan untuk mengukur kegiatan pegawai dengan menghitung waktu yang digunakan untuk bekerja serta waktu yang tidak digunakan untuk bekerja dalam jam kerja mereka, sesudah itu disajikan dalam bentuk persentase (Maretno \& Haryono, 2015).

Penentuan jumlah tenaga kerja tidak terlepas dari seberapa besar volume pekerjaan yang ditargetkan untuk diselesaikan dalam tiap siklus kerja baik hari, bulan, maupun tahun, dalam hal ini target volume pekerjaan, waktu baku, jumlah hari kerja, dan jam kerja merupakan acuan penyelesaian. Beberapa penelitian menyarankan penambahan jumlah tenaga kerja untuk mengurangi beban kerja yang berlebih dan mengoptimalkan sistem kerja yang ada (Jasri, 2016; Farhana, 2020; Akuba, 2019; Ihsan, 2019).

PT. XYZ merupakan perusahaan pangan yang memproduksi tepung terigu dengan berbagai macam varian dengan fungsi dan kegunaan masing-masing serta mempunyai pangsa pasar yang cukup luas baik dalam ataupun luar provinsi dengan jam kerja terbagi menjadi 3 shift. PT XYZ khususnya pada departemen Quality Control memiliki beberapa prosedur analisa berdasarkan job desk yang ditentukan perusahaan untuk memastikan produk selama proses produksi tidak menyimpang terhadap standar kualitas perusahaan. Job Desk tersebut yaitu analisa wajib, Conventional MPA analysis, dan Complete Full Analysis. Pada bulan November 2016, PT. XYZ meningkatkan kapasitas produksi dengan membangun plant produksi baru sehingga sampel analisa pun bertambah sesuai dengan kapasitas produksi perusahaan. Prosedur yang ditetapkan perusahaan terhadap Job Desk analisa wajib departemen Quality Control sebanyak 311 output hasil analisa yang harus diselesaikan setiap shift. Berdasarkan data di lapangan, pekerja dengan job desk analisa wajib yang hanya satu orang tiap shift tidak dapat menyelesaikan pekerjaannya tepat waktu sesuai jam kerja normal, sehingga output tersebut dapat dikatakan tidak seimbang dengan jumlah pekerja yang dipekerjakan pada job desk analisa wajib. Ketidakseimbangan ini dikarenakan sample yang diuji berjumlah lebih banyak sehingga job desk ini tidak bisa dituntaskan oleh satu orang pekerja. Pada saat beban kerja lebih besar dari kapasitas pekerja, pasti terdapat dampak buruk yang akan terjadi. Penyesuaian antara beban kerja dengan keterampilan dari pekerja sangatlah penting guna menunjang tingkat produktivitas dari perusahaan untuk lebih baik. Apabila pekerja sudah mengalami kelebihan beban kerja baik itu mental maupun fisik, dibutuhkan pemulihan tenaga antara lain merupakan lamanya waktu rehat, periode rehat, dan frekuensi rehat (Pracinasari, 2013).

Perencanaan tenaga kerja yang baik sesuai dengan beban kerja berdampak pada optimalisasi pekerjaan tetap terjaga dan menghasilkan produktivitas pekerja yang baik guna mempertahankan konsistensi kualitas tepung terigu. Aspek beban kerja diperlukan dalam penentuan kebutuhan tenaga kerja, Analisis beban kerja dalam penelitian menggunakan metode Workload Analysis dengan tujuan untuk mengetahui waktu baku yang dibutuhkan untuk menyelesaikan pekerjaan dalam shift kerja serta menentukan jumlah karyawan optimal berdasarkan beban kerja yang terjadi pada departemen quality control PT. XYZ bagian analisa wajib.

\section{METODE PENELITIAN}

Sebelum mengaplikasikan workload analysis hal yang mesti diukur yaitu kegiatan produktif maupun non-produktif karyawan. Kegiatan produktif karyawan ialah kegiatan saat karyawan melakukan pekerjaan, sedangkan kegiatan non-produktif karyawan ialah ketika karyawan menggunakan waktu kerja untuk aktivitas pribadi (personal times), kelelahan (fatigue), waktu menunggu (waiting), ketidakhadiran (not available) serta mencari perlengkapan (Wibawa et al., 2015). Rating Factor digunakan untuk menentukan performance rating. Dengan pendekatan terhadap Skill (Keterampilan), Effort (Usaha), Conditions (Kondisi), Consistency (Konsistensi) sesuai dengan tabel Westinghouse rating system dapat diketahui tingkat penyesuaian pekerja dalam menyelesaikan pekerjaannya. Nilai dari tabel penyesuaian tersebut kemudian ditambah dengan nilai satu. Nilai satu tersebut ialah nilai syarat pada saat karyawan bekerja normal (Maghfirotika, 2016).

Dalam studi ini dilakukan pengukuran beban kerja secara langsung menggunakan sampling kerja. dengan waktu yang lebih singkat dan biaya tidak terlalu besar membuat metode ini lebih efisien (Nurjannah, 2009). Langkah awal pengolahan data adalah menghitung persentase produktif dan non-produktif. 
$\%$ produktif $=\frac{\text { Jumlah produktif }}{\text { Jumlah pengamatan }} \times 100 \%$

$\%$ Delay $=\frac{\text { Jumlah Idle }}{\text { Jumlah pengamatan }} \times 100 \%$

Ratio Delay $=\frac{\text { Persentase Idle }}{\text { Persentase Produktifitas }} \times 100 \%$

Pengujian kecukupan data bertujuan untuk menentukan bahwa informasi yang kita ambil telah layak mewakili ataupun belum. Pada riset ini digunakan derajat kepercayaan sebesar 95\% dengan nilai $\mathrm{k}=2$, sedangkan derajat ketelitian sebesar 5\%. Data dinyatakan memadai jika N' lebih kecil dari N. N' merupakan banyaknya pengamatan yang dibutuhkan, $\mathrm{K}$ adalah harga indek yang besarnya tergantung dari tingkat kepercayaan yang diambil, $\mathrm{S}$ adalah tingkat ketelitian yang dikehendaki dan $\overline{\mathrm{P}}$ merupakan produktivitas rata-rata pekerja (Wignjosoebroto, 2003)

$N^{\prime}=\frac{k^{2}(1-\bar{P})}{s^{2} \bar{P}}$

Uji keseragaman data dilakukan untuk mengetahui apakah data yang didapat telah seragam dan tidak melampaui batas kontrol atas (BKA) maupun batas kontrol bawah (BKA). Penentuan batas ini akan dipengaruhi oleh presentasi produktif $(\overline{\mathrm{P}})$ dan tingkat ketelitian $(\mathrm{K})$.

$$
\begin{aligned}
& B K A=\bar{P}+k \sqrt{\frac{\bar{P}(1-\bar{P})}{\text { Npengamatan }}}
\end{aligned}
$$

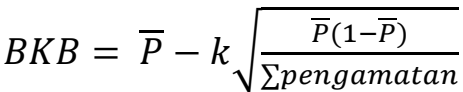

Waktu siklus ialah waktu penyelesaian satu satuan produk semenjak bahan baku mulai diproses di tempat kerja yang bersangkutan (Sutalaksana et al., 2006). Waktu normal merupakan waktu kerja yang telah mempertimbangkan Rating factor, yaitu waktu siklus ratarata dikalikan dengan faktor penyesuaian. Untuk menghitung Waktu normal harus dapat diketahui rating factor pekerja terlebih dahulu. Waktu baku merupakan waktu terbaik yang dibutuhkan oleh pekerja normal dalam menyelesaikan suatu tugas atau pekerjaan. Waktu baku dapat dihitung setelah waktu siklus dan waktu normal diketahui terlebih dahulu dengan penyesuaian tingkat kelonggaran atau Allowance pekerja. Perhitungan Produksi Output Standar (JOS) bertujuan untuk membandingan antara jumlah jam kerja yang digunakan oleh pekerja dalam menyelesaikan pekerjaannya dibanding dengan waktu baku pengerjaan per unit.
$W S=\frac{\text { total waktu } x \text { persentase produktif }}{\text { jumlah output yang dihasilkan }}$

$W n=\frac{\text { total waktu } \times \text { persentase produktif } \times R f}{\text { jumlah output yang dihasilkan }}$

$W b=W n \times \frac{100 \%}{100 \%-\text { allowance }(\%)}$

$J O S=\frac{\text { jam kerja perhari }(\text { menit })}{\text { Waktu Baku }(W b)}$

Penentuan Workload Analysis (WLA) tidak terlepas dari seberapa besar volume pekerjaan yang ditargetkan untuk diselesaikan dalam tiap siklus kerja baik hari, bulan, maupun tahun, dalam hal ini target volume pekerjaan (Q), waktu baku (Wb), jumlah hari kerja (Hk), dan jam kerja merupakan acuan penyelesaian (Jk) (Abidin 2016).

$W L A=\frac{Q-W b}{H k \times J k} \times 1$ orang

\section{HASIL DAN PEMBAHASAN}

Kegiatan produktif dan non-produktif pekerja dapat diketahui pada saat pengamatan sampling kerja dengan membandingkan kegiatan pekerja berdasarkan job description dengan kegiatan yang sebenarnya dilakukan selama melaksanakan pekerjaan. Persentase produktif dan non-produktif pekerja dipengaruhi oleh aktivitas yang dilakukan pekerja selama bekerja. Persentase non-produktif ini dipengaruhi oleh berbagai macam aktivitas pekerja ketika menggunakan waktu kerja untuk kegiatan diluar pekerjaan seperti pergi ke kamar mandi, berbincang dengan rekan kerja, makan \& minum, bermain smartphone, beristirahat sebentar, membantu pekerjaan teman yang tidak sebidang. Rekapitulasi data data kegiatan produktif dan non-produktif pekerja selama pengamatan sesuai dengan Tabel 1.

Tabel 1. Data Pengamatan Sampling kerja

\begin{tabular}{cccccc}
\hline $\begin{array}{c}\text { Tanggal } \\
\text { Pengamatan }\end{array}$ & $\begin{array}{c}\text { Jumlah } \\
\text { Pengam } \\
\text { atan }\end{array}$ & $\begin{array}{c}\text { Kegiatan } \\
\text { Produktif }\end{array}$ & $\begin{array}{c}\text { Persen Juml } \\
\text { tase } \\
\text { Produk } \\
\text { tif (\%) }\end{array}$ & $\begin{array}{c}\text { Idle } \\
\text { Id }\end{array}$ & $\begin{array}{c}\text { Persentase } \\
\text { Idle } \\
(\%)\end{array}$ \\
\hline $01-11-20$ & 20 & 18 & 0.90 & 2 & 0.10 \\
$02-11-20$ & 20 & 18 & 0.90 & 2 & 0.10 \\
$04-11-20$ & 20 & 17 & 0.85 & 3 & 0.15 \\
$05-11-20$ & 20 & 18 & 0.90 & 2 & 0.10 \\
$06-11-20$ & 20 & 18 & 0.90 & 2 & 0.10 \\
$07-11-20$ & 20 & 17 & 0.85 & 3 & 0.15 \\
$08-11-20$ & 20 & 18 & 0.90 & 2 & 0.10 \\
$09-11-20$ & 20 & 18 & 0.90 & 2 & 0.10 \\
$11-11-20$ & 20 & 18 & 0.90 & 2 & 0.10 \\
$12-11-20$ & 20 & 18 & 0.90 & 2 & 0.10 \\
\hline Total & 200 & 178 & 8.9 & 22 & 1.10 \\
\hline
\end{tabular}




$$
\begin{array}{ll}
\text { Persentase Produktif } & =\frac{8.9}{10} \times 100 \%=0.89 \\
\text { Persentase Delay } & =\frac{1.1}{10} \times 100 \%=0.11 \\
\text { Ratio Delay } & =\frac{0.11}{0.89}=0.1236
\end{array}
$$

Data hasil pengukuran beban kerja yang dilakukan di PT. XYZ departemen Quality Control terhadap operator dengan jobdesk analisa wajib sebanyak 200 kali pengamatan yang menghasilkan data total jumlah produktif sebanyak 178 unit dan 22 unit idle. Persentase produktif pekerja sebesar 0.89, persentase Delay pekerja sebesar 0.11 dengan ratio delay sebesar 0.1236. Hal tersebut menunjukkan pekerja melakukan pekerjaan secara efisien dan dari efisiensi tersebut keseimbangan dalam tahapan pekerjaan lebih terjaga serta ketidakpastian lebih controllable.

Pengujian kecukupan data untuk memastikan data yang digunakan dalam penelitian sudah mencukupi dengan kriteria N' lebih kecil dari N. N' merupakan jumlah pengamatan yang harus dilakukan untuk sampling kerja yang dicari menggunakan rumus diatas. Setelah perhitungan hasil N' dengan tingkat kepercayaan 95\% dan tingkat ketelitian sebesar $5 \%$ maka jumlah N' sebanyak 198. N' harus lebih kecil atau sama dengan dari $\mathrm{N}$, maka dengan hasil diatas tersebut data dianggap cukup. Perhitungan uji keseragaman data operator Quality Control khususnya pada analisa wajib diperoleh Batas Kontrol Atas (BKA) sebesar 0.9342 dan Batas Kontrol Bawah (BKB) sebesar 0.8457 dengan persentase produktivitas sebesar 0.89 (Gambar 1). Hal tersebut menjelaskan bahwa data yang digunakan telah seragam karena data berada dalam batas kontrol dan tidak ada yang menyimpang.

$N^{\prime}=\frac{2^{2}(1-0.89)}{0.05^{2} \times 0.89}=197.75 \approx 198$

$B K A=0.89+2 \sqrt{\frac{0.89(1-0.89)}{200}}=0,9342$
$B K A=0.89-2 \sqrt{\frac{0.89(1-0.89)}{200}}=0.8457$

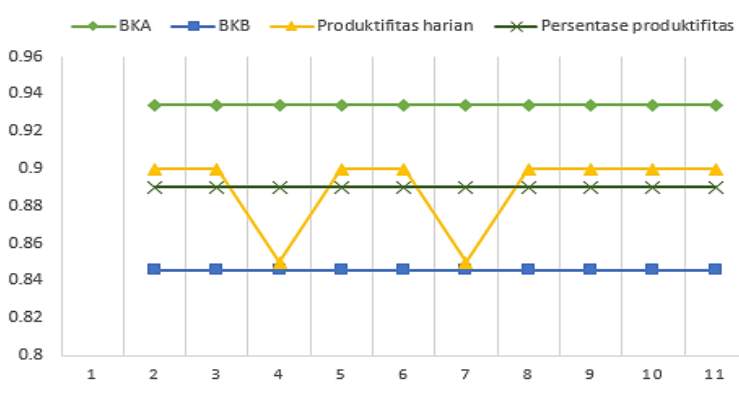

Gambar 1. Peta Kontrol Keseragaman Data
Penentuan waktu siklus berdasarkan jumlah pengamatan yang dilakukan selama 10 hari dengan 7 jam kerja. Total pengamatan selama 10 hari adalah selama 4200 menit. Berdasarkan data tersebut maka diketahui waktu siklus pekerjaan sebesar 2,45 menit.

$\mathrm{Ws}=\frac{4200 \times 0.89}{1527}=2.45$ menit

Setelah diketahui nilai waktu siklus, selanjutnya dapat dicari watu normal pekerja dengan penyesuaian rating factor. Faktor-faktor yang digunakan dalam menentukan rating factor antara lain keterampilan, usaha, kondisi kerja dan konsistensi. Rating factor (RF) dalam

\begin{tabular}{|c|c|c|c|c|c|}
\hline No & Faktor & Kelas I & mbang & $\begin{array}{l}\text { Peny } \\
\text { esuai }\end{array}$ & Keterangan \\
\hline 1 & $\begin{array}{l}\text { Keteram } \\
\text { pilan }\end{array}$ & $\begin{array}{c}\text { Excell } \\
\text { ent }\end{array}$ & B2 & +0.08 & $\begin{array}{c}\text { Tampak cocok } \\
\text { dengan pekerjaannya, } \\
\text { terlihat telah terlatih, } \\
\text { bekerja berirama dan } \\
\text { terkoordinasi }\end{array}$ \\
\hline 2 & Usaha & $\begin{array}{c}\text { Excell } \\
\text { ent }\end{array}$ & B1 & +0.10 & $\begin{array}{c}\text { Penuh perhatian pada } \\
\text { kerjaannya, bekerja } \\
\text { sistematis. }\end{array}$ \\
\hline 3 & $\begin{array}{c}\text { Kondisi } \\
\text { Kerja }\end{array}$ & $\begin{array}{c}\text { i Excell } \\
\text { ent }\end{array}$ & B & +0.06 & $\begin{array}{l}\text { Kondisi terlihat cocok } \\
\text { dengan Operator }\end{array}$ \\
\hline 4 & $\begin{array}{c}\text { Konsiste } \\
\text { nsi }\end{array}$ & e Good & C & +0.01 & $\begin{array}{c}\text { Konsistensi Kerja } \\
\text { Operator pada Level } \\
\text { sedikit diatas rata- } \\
\text { rata. }\end{array}$ \\
\hline
\end{tabular}
penelitian ini sebesar 1.25 (Tabel 2).

Tabel 2. Rating Factor Pekerja

Setelah dilakukan penyesuaian dengan rating factor didapatkan hasil sesuai dengan Tabel 2 yaitu, pekerja tampak cocok dengan pekerjaannya, terlihat telah terlatih, bekerja berirama dan terkoordinasi. Dalam usaha selama proses kerja pekerja penuh perhatian pada kerjaannya, bekerja sistematis, serta konsistensi kerja pada level sedikit diatas rata-rata. Dari data tersebut maka dapat diketahui waktu normal pekerjaan sebesar 3,06 menit.

$\mathrm{Wn}=\frac{4200 \times 0.89 \times 1.25}{1527}=3.06$ menit

Waktu baku dapat dihitung setelah diketahui data waktu normal dengan penyesuaian tinggal allowance pekerja. Jenis allowance yang digunakan dalam penelitian ini antara lain tenaga yang dikeluarkan, sikap kerja, gerakan kerja, kelelahan mata, keadaan temperatur dan keadaan atmosfer (Tabel 3). Waktu standar atau waktu baku pekerja dengan penyesuain terhadap allowance berdasarkan kondisi pekerja dan kondisi lingkungan kerja dengan nilai waktu baku sebesar 3.71 menit. 
Tabel 3. Tingkat Allowance Pekerja

\begin{tabular}{|c|c|c|c|c|}
\hline No. & $\begin{array}{l}\text { Jenis } \\
\text { Allowance }\end{array}$ & Faktor & $\begin{array}{l}\text { Contoh } \\
\text { Pekerjaan }\end{array}$ & $\begin{array}{c}\text { Kelongga } \\
\text { an (\%) }\end{array}$ \\
\hline 1 & $\begin{array}{l}\text { Tenaga yang } \\
\text { dikeluarkan }\end{array}$ & $\begin{array}{l}\text { Sangat } \\
\text { ringan }\end{array}$ & $\begin{array}{l}\text { Bekerja di } \\
\text { meja, berdiri, } \\
\text { dan tanpa } \\
\text { beban. }\end{array}$ & 6.0 \\
\hline 2 & Sikap Kerja & $\begin{array}{l}\text { Berada } \\
\text { diatas } \\
\text { dua kaki }\end{array}$ & $\begin{array}{c}\text { Badan tegak, } \\
\text { ditumpu } \\
\text { dengan dua } \\
\text { kaki. }\end{array}$ & 2.0 \\
\hline 3 & $\begin{array}{c}\text { Gerakan } \\
\text { Kerja }\end{array}$ & Normal & $\begin{array}{c}\text { Ayunan kerja } \\
\text { bebas. }\end{array}$ & 0 \\
\hline 4 & $\begin{array}{l}\text { Kelelahan } \\
\text { Mata }\end{array}$ & $\begin{array}{l}\text { Pandang } \\
\text { an terus } \\
\text { menerus } \\
\text { dengan } \\
\text { fokus } \\
\text { berubah- } \\
\text { ubah }\end{array}$ & $\begin{array}{l}\text { Memeriksa } \\
\text { cacat pada } \\
\text { produk. }\end{array}$ & 7.5 \\
\hline 5 & $\begin{array}{c}\text { Keadaan } \\
\text { Temperature }\end{array}$ & Sedang & $\begin{array}{l}\text { Suhu antara } \\
13^{\circ} \mathrm{C}-22^{\circ} \mathrm{C}\end{array}$ & 2.0 \\
\hline 6 & $\begin{array}{l}\text { Keadaan } \\
\text { atmosfer }\end{array}$ & Baik & $\begin{array}{c}\text { Ruangan } \\
\text { dengan udara } \\
\text { segar. }\end{array}$ & 0 \\
\hline
\end{tabular}

$\mathrm{Wb}=3.06 \times \frac{100 \%}{100 \%-17.5 \%}=3.71$ menit

Perhitungan jumlah output standar dapat diketahui dengan perbandingan antara jam kerja dengan waktu baku pekerja. Berdasarkan 7 jam kerja perhari dan waktu baku sebesar 3.71 menit, jumlah output standar yang didapati sebanyak 113 output. Perhitungan beban kerja dengan metode Workload Analysis berdasarkan target volume pekerjaan, jumlah hari kerja, jam kerja, dan waktu baku, dapat dihitung sebagai berikut:

$\mathrm{WLA}=\frac{3110-0.0618}{10 \times 7} \times 1$ orang $=2.75 \approx 3$ orang

Pekerjaan yang dialami oleh karyawan PT. XYZ departemen Quality Control bagian analisa wajib dapat diselesaikan oleh 2.75 orang atau sebanyak 3 orang, hal tersebut disebabkan karena volume pekerjaan yang diberikan terlalu banyak namun jumlah pekerja pada bagian tersebut tidak sepadan. Hal ini menunjukkan metode work sampling dapat diaplikasikan dan diterapkan dalam mengatasi permasalahan beban kerja (Jasri, 2016). Pada penelitian ini penentuan jumlah tenaga kerja digunakan metode Workload Analysis, sehingga dalam penentuan tenaga kerja optimal tidak hanya berdasarkan waktu baku, melainkan juga dengan memertimbangkan target volume pekerjaan, jumlah hari kerja, dan jam kerja operator.

\section{KESIMPULAN}

Berdasarkan hasil pengumpulan dan pengolahan data selama 10 hari kerja tertanggal
01 November 2019 hingga 12 November 2019 dapat disimpulkan bahwa pengukuran waktu baku menggunakan diperoleh waktu baku sebesar 3.71 menit atau 0.0618 jam. Pengukuran jumlah tenaga kerja menggunakan metode workload analysis diperoleh jumlah tenaga kerja pada job desk analisa wajib sebanyak 3 orang. Penelitian selanjutnya dapat dilakukan dengan melakukan pengukuran beban kerja mental sehingga ada pembanding antara beban kerja fisik dan beban kerja mental.

\section{DAFTAR PUSTAKA}

Abidin, F. (2016). Analisis Kebutuhan Jumlah Pegawai Berdasarkan Metode Work Load Analysis dan Work Force Analysis (Studi Kasus Kerajinan Blangkon Di Serengan). Skripsi. Universitas Muhammadiyah Surakarta). http://eprints.ums.ac.id/42333/

Ahmad, K. (2004). Dasar-dasar manajemen Investasi dan Portofolio. Jakarta: Rineka. Cipta.

http://elib.unikom.ac.id/download.php?id=34 0647

Akuba, Z., Lasalewo, T., \& Junus, S. (2019). Analisis Beban Kerja Untuk Menentukan Jumlah Pegawai Optimal Dengan Metode Work Load Analysis (Studi Kasus: Tenaga Penunjang Akademik Fakultas Teknik Universitas Negeri Gorontalo). In SemanTECH (Seminar Nasional Teknologi, Sains dan Humaniora), pp. 300308.

http://jurnal.poligon.ac.id/index.php/semante ch/article/view/493

Anisa, H. N., \& Prastawa, H. (2019). Analisis Beban Kerja Pegawai Dengan Metode Full Time Equivalent (FTE)(Studi Kasus pada PT. PLN (Persero) Distribusi Jateng dan DIY). Industrial Engineering Online Journal, 7(4), $\quad$ 1-8. https://ejournal3.undip.ac.id/index.php/ieoj/a rticle/view/22988

Budaya, P. W., \& Muhsin, A. (2018). Workload analysis in quality control department. Opsi, 11(2), 134-140. http://jurnal.upnyk.ac.id/index.php/opsi/articl e/view/2554

Farhana, D. H. (2020). Analisis Beban Kerja Dalam Menentukan Jumlah Tenaga Kerja Optimal Dengan Metode Workload Analysis (WLA) Di PT Jaya Teknik Indonesia. SIJIE Scientific Journal of Industrial Engineering, 1(2), 18-22. http://jim.unindra.ac.id/index.php/sijie/article /view/115

Hariyati, M. (2011). Pengaruh Beban Kerja Terhadap Kelelahan Kerja Pada Pekerja 
Linting Manual di PT Djitoe Indonesia Tobacco Surakarta. Skripsi . Surakarta: Fakultas Kedokteran UNS. https://eprints.uns.ac.id/8474/

Ihsan, M., Fathimahhayati, L. D., \& Pawitra, T. A. (2019). Analisis Beban Kerja dan Penentuan Tenaga Kerja Optimal dengan Metode Workload Analisis dan ECRS. JIME (Journal of Industrial and Manufacture Engineering), 3(2), http://www.ojs.uma.ac.id/index.php/jime/arti cle/view/2647

Jasri, H. (2016). Analisa Beban Kerja Fisik Operator pada Stasiun Packing melalui Pendekatan Work Sampling. Jurnal Teknik Industri: Jurnal Hasil Penelitian dan Karya IImiah dalam Bidang Teknik Industri, 2(1), 9-17. http://ejournal.uinsuska.ac.id/index.php/jti/article/view/6429

Maghfirotika, N. (2016) Penentuan Jumlah Optimal Karyawan Produksi JTOP Dengan Metode Workload Analysis di PT. Y. Skripsi. https://repository.ipb.ac.id/handle/12345678 9/86771

Maretno, A., \& Haryono, H. (2015). Analisa Beban Kerja Fisik dan Mental dengan Menggunakan Work Sampling dan NASATLX Untuk Menentukan Jumlah Operator. Dinamika Rekayasa, 11(2), 55- 63.http://dinarek.unsoed.ac.id/jurnal/index.p $\mathrm{hp} / \mathrm{dinarek} /$ article/view/73

Nurjannah, P. (2009). Penentuan Jumlah Tenaga Kerja Berdasarkan Waktu Standar Dengan Metode Work Sampling Di Bagian Packing Pada PT. Sinar Oleochemical International. Skripsi. Universitas Sumatera Utara. http://repository.usu.ac.id/handle/12345678 9/11931

Pracinasari, I. (2013). Beban Kerja Fisik Vs Beban Kerja Mental. https://www.coursehero.com/file/50572041/ 2509100006-Undergraduate-Thesespdf

Sutalaksana, I. Z., Anggawisastra, R., \& Tjakraatmadja, J. H. (2006). Teknik perancangan sistem kerja. Bandung: ITB.

Wibawa, R. P. N., Sugiono, S., \& Efranto, R. Y. (2014). Analisis Beban Kerja Dengan Metode Workload Analysis Sebagai Pertimbangan Pemberian Insentif Pekerja (Studi Kasus di Bidang PPIP PT Barata Indonesia (Persero) Gresik). Jurnal Rekayasa dan Manajemen Sistem Industri, 2(3), 672-683. http://jrmsi.studentjournal.ub.ac.id/index.php /jrmsi/article/view/117/151

Wignjosoebroto, S. (2003). Ergonomi studi gerak dan waktu. Surabaya: Guna Widya 